\title{
Reduced expression of thyroid hormone receptors and beta- adrenergic receptors in human failing cardiomyocytes
}

\author{
Pietro Amedeo Modesti ${ }^{a, *}$, Matilde Marchetta ${ }^{a}$, Tania Gamberi ${ }^{a}$, Gianluca Lucchese ${ }^{b}$, \\ Massimo Maccherini ${ }^{b}$, Mario Chiavarelli ${ }^{b}$, Alessandra Modesti ${ }^{a}$ \\ a Department of Critical Care Medicine, University of Florence, Viale Morgagni 85, 50134 Florence, Italy \\ ${ }^{\mathrm{b}}$ Department of Cardiothoracic Surgery, University of Siena, Siena, Italy
}

\section{A R T I C L E I N F O}

Article history:

Received 10 August 2007

Accepted 9 October 2007

Keywords:

Heart failure

Cardiomyopathy

3,5,3'-Triiodo-L-thyronine

Myocytes

\begin{abstract}
A B S T R A C T
An altered thyroid hormone profile has been reported in patients with congestive heart failure. However, information regarding the status of thyroid hormone receptors in human failing cardiomyocytes is lacking. Therefore the expression of thyroid hormone and betaadrenergic receptors was investigated in human ventricular cardiomyocytes isolated from patients with end-stage heart failure (FM, $n=12)$, or from tentative donors $(C, n=4)$. The expression of thyroid (TRalpha1, and TRbeta1) and beta-adrenergic receptors (ARB1 and ARB2) was measured at both the gene, and at the protein level.

In FM the reduced mRNA expression of ARB1 $(p<0.05,-37 \%)$ and ARB2 $(p<0.05,-42 \%)$ was associated with a reduction of the messenger for TRalpha1 $(p<0.05,-85 \%)$ and TRalpha2 $(p<0.05,-73 \%)$. These findings were confirmed at the protein level for ARB1, ARB2 and TRalpha1.

These data reveal that in human heart failure the reduction of beta-adrenergic receptors is associated with reduced expression of both TRalpha1 and TRalpha2 isoforms of thyroid hormone receptors.
\end{abstract}

(C) 2007 Elsevier Inc. All rights reserved.

\section{Introduction}

Many of the clinical manifestations of thyroid diseases are mediated by changes in cardiovascular hemodynamics [1]. These changes, in particular heart rate, are known to improve in response to treatment with beta-adrenergic receptor antagonists [2]. 3,5,3'-Triiodo-L-thyronine (T3) was indeed reported to affect cardiac function by enhancing the expression of genes involved in the regulation of beta-adrenergic signalling, such as sarcoplasmic reticulum $\mathrm{Ca}^{2+}$ ATPase [3], and of the beta-adrenergic receptor itself [4], in addition to its effects on the expression of other cardiac specific genes [3-7]. This aspect is particularly important in the treatment of thyroid storm disease where the use of beta-adrenergic antagonism is a priority. On the other hand, human studies have shown that the progression to failure is characterized not only by a significant reduction of adrenergic receptors [8], but also by cardiac changes in phenotype and gene expression similar to those described for hypothyroidism [9-11]. A low triiodiothyronine (T3) syndrome, characterized by low circulating levels of the biologically active form of $\mathrm{T} 3$ in the presence of normal thyrotropin (TSH) and of thyroxine was indeed reported to occur in approximately $30 \%$ of patients with advanced heart failure [12]. However, a reduced expression of cardiac genes stimulated by thyroid hormone was observed also in explanted hearts removed from patients who were clinically and chemically euthyroid $[9,13,14]$. Therefore a potential alteration of cardiac T3 signal transduction in failing heart was hypothesized so that several studies investigated the expression of receptors for thyroid hormone

\footnotetext{
* Corresponding author. Tel.: +39055 7949376; fax: +39 0557949376.

E-mail address: pamodesti@unifi.it (P.A. Modesti).

0006-2952/\$ - see front matter (C) 2007 Elsevier Inc. All rights reserved. doi:10.1016/j.bcp.2007.10.011
} 
in homogenated human failing hearts. However, those studies gave conflicting results because either a decrease $[15,16]$ or an increase [17] in the expression of the physiologically active alpha1 isoform of T3 receptor was found. Most importantly, notwithstanding the recognized effects of T3 on cardiac contractility, investigations assessing the T3 receptor population on cardiac contractile cells in human heart failure are lacking. Therefore the aims of the present study were to investigate the expression of TRs and beta-adrenergic receptors in ventricular cardiomyocytes isolated from human failing hearts.

\section{Materials and methods}

\subsection{Subjects investigated}

Hearts were obtained from 12 patients $(n=12$, aged $58 \pm 2$ years) with end-stage dilated cardiomyopathy (DCM) scheduled to undergo cardiac transplantation. Diagnosis of dilated cardiomyopathy was based on clinical and echocardiographic examination and coronary angiography. Subjects with arterial hypertension, history of ischemic heart disease or myocardial infarction, and echocardiographic evidence of valve or congenital heart disease were not considered for the study. Exclusion criteria for patients and controls were also the history of thyroid disease and therapy with amiodarone, thyroid hormone and use of dopamine during a period of 4 weeks preceding the study. Hearts obtained from four putative organ donors ( $n=4$, aged $54 \pm 5$ years) with no histories or signs of heart disease, whose hearts could not be transplanted because of non-cardiac reasons (non-failing hearts, NF) served as controls. Characteristics of subjects investigated are reported in Table 1. Serum TSH, free $T_{4}\left(\mathrm{fT}_{4}\right)$, and free $\mathrm{T}_{3}$ $\left(\mathrm{fT}_{3}\right)$ levels were determined by means of commercial kits (Abbott, Chicago, USA).

The protocol of this study complies with the principles of the Helsinki declaration and was approved the review committee of our Institution and by MIUR (Ministero Italiano Università e Ricerca, project 2003, no. 2003063257). All patients gave their informed written consent to participate and to have their hearts used for the study.

\subsection{Cardiac tissue and myocyte isolation}

Heart was placed in ice-cold oxygenated physiological salt solution immediately after removal. One gram transmural specimens was taken within 10 min of explantation from the central portion of left ventricular free wall, immediately frozen in liquid nitrogen, and stored at $-80^{\circ} \mathrm{C}$ until use. The heart was then immediately transported to the laboratory where myocytes were isolated with enzymatic digestion method as previously described $[18,19]$. In details a coronary artery branch was cannulated and perfused for 10-15 min with a low calcium buffer (Basic Buffer, BB). Basic Buffer was composed by Jocklic buffer (Sigma M0518) supplemented with $0.3 \mathrm{~g} / \mathrm{L}$ glutamine (Sigma G6201), $1.25 \mathrm{~g} / \mathrm{L}$ taurine (Sigma T0625), $2.9 \mathrm{mmol} / \mathrm{L}$ HEPES (Sigma H3375), $20 \mathrm{U} / \mathrm{L}$ insulin, $10 \mathrm{~mL} / \mathrm{L}$ penicillin-streptomycin (Sigma P0781, $5000 \mathrm{U} / \mathrm{mL}$ penicillin and $5 \mathrm{mg} / \mathrm{mL}$ streptomycin), and $7.5 \mu \mathrm{mol} / \mathrm{L} \mathrm{CaCl}_{2}$,
Table 1 - Clinical characteristics of subjects investigated

\begin{tabular}{|c|c|c|}
\hline & NF & DCM \\
\hline Age (years) & $54 \pm 5$ & $58 \pm 2$ \\
\hline Sex (M/F) & $3 / 1$ & $9 / 3$ \\
\hline Body surface area $\left(\mathrm{m}^{2}\right)$ & $1.8 \pm 0.1$ & $2.0 \pm 0.2$ \\
\hline $\begin{array}{l}\text { New York Heart Association } \\
\text { class (III/IV) }\end{array}$ & - & $6 / 0$ \\
\hline $\begin{array}{l}\text { Left ventricular end diastolic } \\
\text { diameter index }\left(\mathrm{mm} / \mathrm{m}^{2}\right)\end{array}$ & $26 \pm 4$ & $44 \pm 7^{*}$ \\
\hline Left ventricular mass index $\left(\mathrm{g} / \mathrm{m}^{2}\right)$ & $100 \pm 15$ & $270 \pm 50^{*}$ \\
\hline Ejection fraction (\%) & $60 \pm 3$ & $26 \pm 4^{*}$ \\
\hline Cardiac index $\left(\mathrm{L} /\left(\min \mathrm{m}^{2}\right)\right)$ & - & $1.8 \pm 0.3$ \\
\hline $\begin{array}{l}\text { Mean pulmonary artery } \\
\text { pressure (mmHg) }\end{array}$ & - & $29 \pm 14$ \\
\hline $\begin{array}{l}\text { Left ventricular end diastolic } \\
\text { pressure }(\mathrm{mmHg})\end{array}$ & - & $16 \pm 3$ \\
\hline $\begin{array}{l}\text { Pulmonary capillary wedge } \\
\text { pressure }(\mathrm{mmHg})\end{array}$ & - & $19 \pm 11$ \\
\hline End systolic stress $\left(\mathrm{kdyn} / \mathrm{cm}^{2}\right)$ & - & $100 \pm 20$ \\
\hline End diastolic stress $\left(\mathrm{kdyn} / \mathrm{cm}^{2}\right)$ & - & $22 \pm 5$ \\
\hline $\begin{array}{l}\text { Serum-free triiodothyronine } \\
\text { (fT3) }(\mathrm{pg} / \mathrm{mL})\end{array}$ & $3.1 \pm 0.2$ & $2.5 \pm 0.3^{*}$ \\
\hline $\begin{array}{l}\text { Serum-free thyroxine } \\
\text { (fT4) }(\mathrm{mg} / \mathrm{L})\end{array}$ & $17.5 \pm 3.5$ & $16.0 \pm 3.0$ \\
\hline $\begin{array}{l}\text { Thyroid-stimulating } \\
\text { hormone (TSH) }(\mu \mathrm{U} / \mathrm{mL})\end{array}$ & $1.45 \pm 0.5$ & $1.30 \pm 0.8$ \\
\hline${ }^{*} p<0.05$ vs. NF. & & \\
\hline
\end{tabular}

pH 7.4. The Basic Buffer was previously leaked through filters by $0.2 \mu \mathrm{m}$ pore. Perfusion was then switched to collagenase solution for 20-25 min. Collagenase solution was composed by collagenase type II (Sigma C6885, $100 \mathrm{U} / \mathrm{mL}, 20 \mathrm{~mL} / \mathrm{min}$ ) in Basic Buffer. The collagenase-perfused tissue was then minced and shaken for approximately $20 \mathrm{~min}$ in Basic Buffer. The suspension was then filtered through a sterile gauze to separate cells from tissue mass. The suspension was allowed to sediment for $10 \mathrm{~min}$ to separate dead cells from those alive that sediment more fastly. Supernatant was aspirated off up to $15 \mathrm{~mL}$. Basic Buffer was then added up to $30 \mathrm{~mL}$ and the procedure was repeated once. Pellets were then resuspended and smears were made. Rod shaped, trypan blue excluding cells constituted nearly $70 \%$ of all myocytes. Nonmyocytes accounted for less than $2 \%$ of the cells in all groups.

\subsection{Reverse transcriptase-polymerase chain reaction}

RT-PCR experiments were performed both on cardiac samples and on isolated myocytes. Total amount of RNA was extracted with FastRNA Pro Green Kit (Q-Biogen) and then reversetranscribed using TaqMAN Reverse Transcription Reagents kit (Applied Biosystem) according to the manufacturer's instructions. The resulting cDNA was then amplified using specific primers for each isoform of the receptors (Table 2) $[17,20,21]$ with GAPDH used as internal standard. Briefly, PCRs were performed using $50 \mathrm{ng}$ of cDNA, $200 \mu \mathrm{mol} / \mathrm{L}$ dNTP, Taq buffer $1 \times$, Taq polymerase $1 \mathrm{U}$ and 50 pmol of each primer, for 40 PCR cycles. Other PCR parameters are reported in Table 2. To ensure that different amounts of PCRs on myocardial biopsies were not due to markedly different mRNA starting concentrations, PCR analysis for GAPDH was performed on serial twofold dilutions of cDNA for each sample. The last dilution 
Table 2 - Sequences and complementary DNA (CDNA) sizes of primers used for investigation of thyroid hormone receptor alpha1 (THRA1), alpha2 (THRA2) and beta1 (THRB1), of beta-adrenergic receptors beta1 (ARB1) and beta2 (ARB2) and of GAPDH gene expression and their thermal profiles

\begin{tabular}{|c|c|c|c|c|c|}
\hline cDNA & $\mathrm{T}_{\mathrm{m}}\left({ }^{\circ} \mathrm{C}\right)$ & cDNA (bp) & Size & Sequence & Ref. \\
\hline \multirow[t]{2}{*}{ THRA1 } & 55 & 325 & Sense & GGT GCT GCA TGG AGA TCA TG & [16] \\
\hline & & & Antisense & GGA ATG TTG TGT TTG CGG TG & \\
\hline \multirow[t]{2}{*}{ THRA2 } & 55 & 259 & Sense & GGT GCT GCA TGG AGA TCA TG & [16] \\
\hline & & & Antisense & TCG ATC TTG TCC ACA CAC AG & \\
\hline \multirow[t]{2}{*}{ THRB1 } & 55 & 421 & Sense & CGG AGG AGA AGA AAT GTA AAG G & [16] \\
\hline & & & Antisense & GCT TCG GTG ACA GTT TTG ATG & \\
\hline \multirow[t]{2}{*}{ ARB1 } & 55 & 522 & Sense & CTC ACC AAC CTC TTC ATC ATG & [19] \\
\hline & & & Antisense & GAA ACG GCG CTC GCA GCT & \\
\hline \multirow[t]{2}{*}{ ARB1 } & 47 & 371 & Sense & ССТ ССT AAA TTG GAT AGG & [19] \\
\hline & & & Antisense & AGT CTG TTT AGT GTT CTG & \\
\hline \multirow[t]{2}{*}{ GAPDH } & 57 & 983 & Sense & TGA AGG TCG GAG TCA ACG GA & [20] \\
\hline & & & Antisense & CAT GTG GGC CAT GAG GTC CA & \\
\hline
\end{tabular}

giving a positive reaction for GAPDH was used to equalize the amount of cDNA used in each PCR. The PCR products were then separated using a $1 \%$ agarose gel in TAE and the bands were quantified by a densitometer software (Quantity One, BioRad) to calculate the ratio for each isoform to GAPDH [21].

\subsection{Western blot analysis}

Isolated myocytes or myocardial samples were resuspended in ice-cold lyses buffer with protease inhibitors mix for eukaryotic cells [19]. Lyses was performed using FastPrep120 instrument (Bio101 ThermoSavant), keeping samples on ice between two consecutive lyses cycles to avoid heating. Lysates were centrifuged for $10 \mathrm{~min}$ at 13,000 rpm and supernatants were collected. Proteins concentration was assayed with BCA Protein Assay kit (Pierce).

Samples $(50 \mu \mathrm{g})$ were separated by $12 \%$ SDS-PAGE and transferred to a PVDF membrane (Amersham Bioscience). The membranes were incubated over night with non-fat milk (non-fat dry milk Biorad) and rabbit anti-human TRalpha1 (ab5621, Abcam) or rabbit anti-human TRbeta1 antibody (ab5622, Abcam). Then the PVDF membrane was washed twice in PBS and tween $0.01 \%$, and incubated $1 \mathrm{~h}$ at room temperature with anti-rabbit horseradish peroxidase conjugated secondary antibody. After washing, antibody-specific proteins were visualized by chemioluminescent detection system (ECL detection reagents, Amersham Bioscience). The amount of each band was quantified by a densitometer software (Quantity One, BioRad) and normalized using the total protein amount detected by ponceau red solution (Ponceau S solution, Sigma).

\subsection{Receptor binding studies}

Equilibrium binding studies were performed by incubating freshly isolated myocytes $\left(1 \times 10^{6} \mathrm{cell} / \mathrm{mL}\right)$ or cell membranes obtained from homogenated hearts $(300 \mu \mathrm{g} / \mathrm{mL})$ with $100 \mathrm{pmol} / \mathrm{L}$ of $\left[{ }^{125} \mathrm{I}\right]$ iodocyanopindolol (ICYP) $(2000 \mathrm{Ci} / \mathrm{mmol}$, Amersham Biosciences) and increasing concentrations of isoproterenol $(0-100 \mu \mathrm{mol} / \mathrm{L})$ at $22^{\circ} \mathrm{C}$ for $90 \mathrm{~min}$. Receptors subtypes were characterized in competition studies using selective antagonists for adrenergic receptors beta1 (ARB1) (metoprolol) or beta2 (ARB2) (ICI118551). Binding data were analyzed by a non-linear fitting computer program (LIGAND) as previously described [21].

\subsection{Statistics}

Data shown are mean \pm S.D. Individual study groups were compared using the Mann-Whitney rank sum test and multivariate analysis of variance.

\section{Results}

The characteristics of subjects investigated are reported in Table 1. Plasma levels of fT3 were significantly lower in DCM patients than in controls, although no subject had fT3 values lower than reference limits.

\subsection{Expression of 3,5,3'-triiodo-L-thyronine and beta- adrenergic receptors in human failing cardiomyocytes}

\subsubsection{Thyroid hormone receptors}

In myocytes isolated from DCM heart, both TRalpha1 $(0.20 \pm 0.05)$ and TRalpha2/GAPDH mRNA ratio $(0.30 \pm 0.07)$ were significantly reduced when compared to NF myocytes $(1.30 \pm 0.35,-85 \% ; 1.10 \pm 0.40,-73 \%$, respectively, $p<0.05$ for both), while the expression of TRbeta1 was unchanged $(0.30 \pm 0.15$ and $0.30 \pm 0.10$, respectively) (Fig. 1). Likewise the expression of TRalpha1 and TRalpha2 was also reduced in homogenated DCM hearts $(0.30 \pm 0.05$ vs. $0.90 \pm 0.15,-67 \%$ and $0.35 \pm 0.07$ vs. $1.10 \pm 0.20,-68 \%$, respectively, $p<0.05$ for both), with no changes of TRbeta1 mRNA (1.00 \pm 0.30 vs. $0.80 \pm 0.20$ in NF hearts) (Fig. 1).

Western blots for TRalpha1 and TRbeta1 confirmed those results at the protein level both in isolated myocytes, where the protein amount of TRalpha1 was reduced by $22 \%$ when compared to control myocytes (Fig. 2), and in total cardiac tissue where TRalpha1 was reduced by $30 \%$ in comparison to NF hearts (Fig. 2). No changes in TRbeta1 receptor were found 

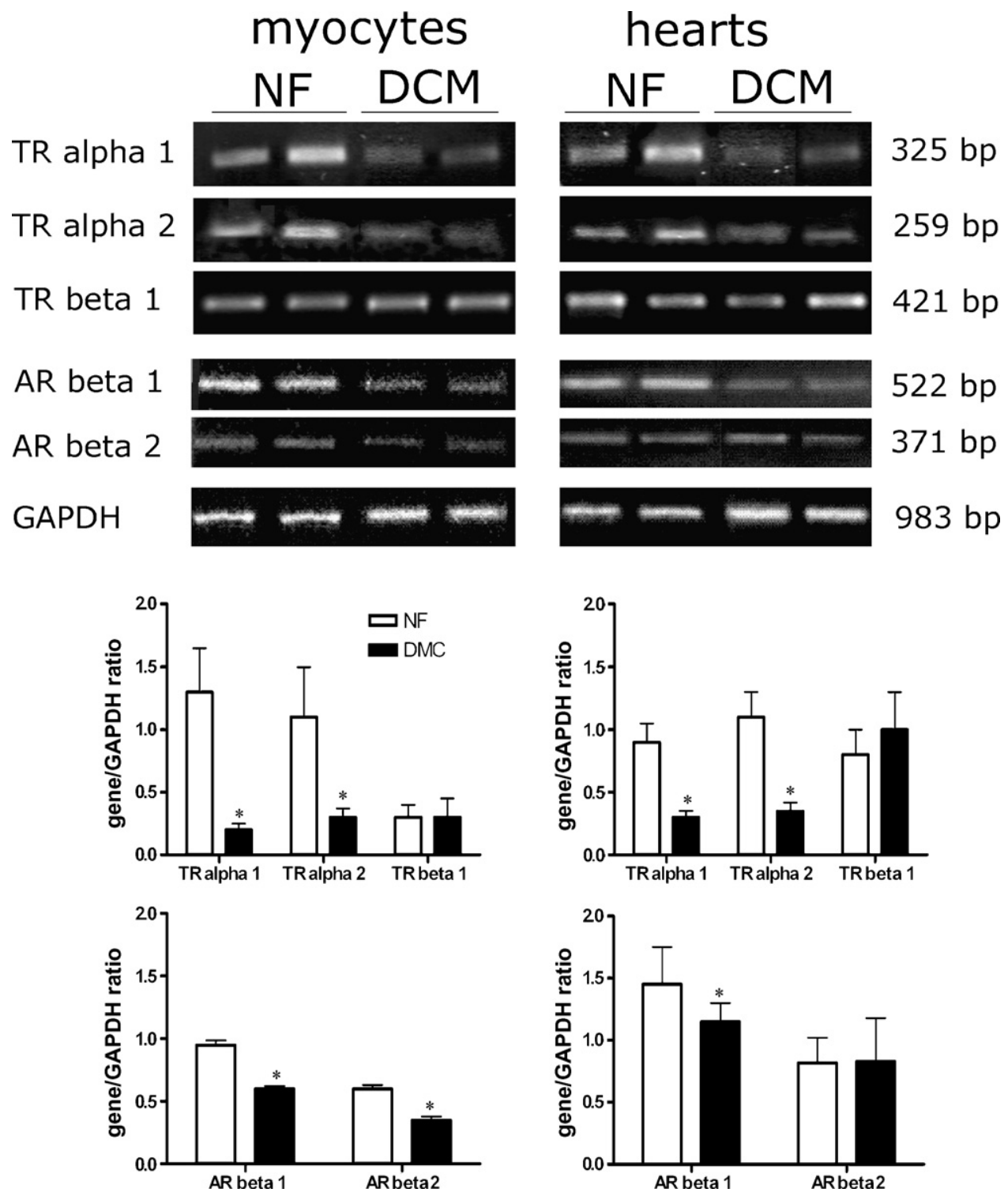

Fig. 1 - mRNA expression of beta1- and beta2-adrenergic receptors, of thyroid hormone receptors alpha1, alpha2 and beta1 and of GAPDH in ventricular cardiomyocytes and homogenated hearts from NF and DCM subjects. Upper panels: Representative RT-PCR experiments. Lower graphs: Bar graphs shows the densitometric cDNA/GAPDH ratio $\left({ }^{*} p<0.05\right.$ vs. NF).

both in myocytes and total cardiac tissue of DCM patients (Fig. 2).

\subsubsection{Beta-adrenergic receptors}

Gene expression of both ARB1 $(0.60 \pm 0.02 \mathrm{mRNA} / \mathrm{GAPDH})$ and ARB2 $(0.35 \pm 0.03)$ are significantly reduced $(-37$ and $-42 \%)$ in myocytes isolated from DCM hearts in comparison to controls ( $0.95 \pm 0.03$ and $0.60 \pm 0.03$, respectively, $p<0.05$ for both) (Fig. 1).

In homogenated DCM heart only ARB1 appears to be significantly reduced $(1.15 \pm 0.15$ and $1.45 \pm 0.30$ in DCM and NF heart, respectively, $p<0.05)$, and the reduction $(-21 \%)$ is lower than that observed in isolated myocytes (Fig. 1).

Those results were confirmed at the protein level by receptor binding assay (Table 3).

\section{Discussion}

The present study investigating thyroid hormone signalling and gene expression in human heart failure revealed lower gene and protein expression for both TRa1 and bARs in isolated human ventricular cardiomyocytes. This is of interest because no investigation were performed to the level of isolated cardiomyocytes. Furthermore, although several other studies on thyroid hormone receptors in human heart failure have been published there is no consensus of results.

A close relation exists between thyroid and adrenergic cardiac receptors [22]. In particular thyroid hormone receptors stimulation was reported to couple to the transcription of bARs [4]. This information has relevant implication in the 


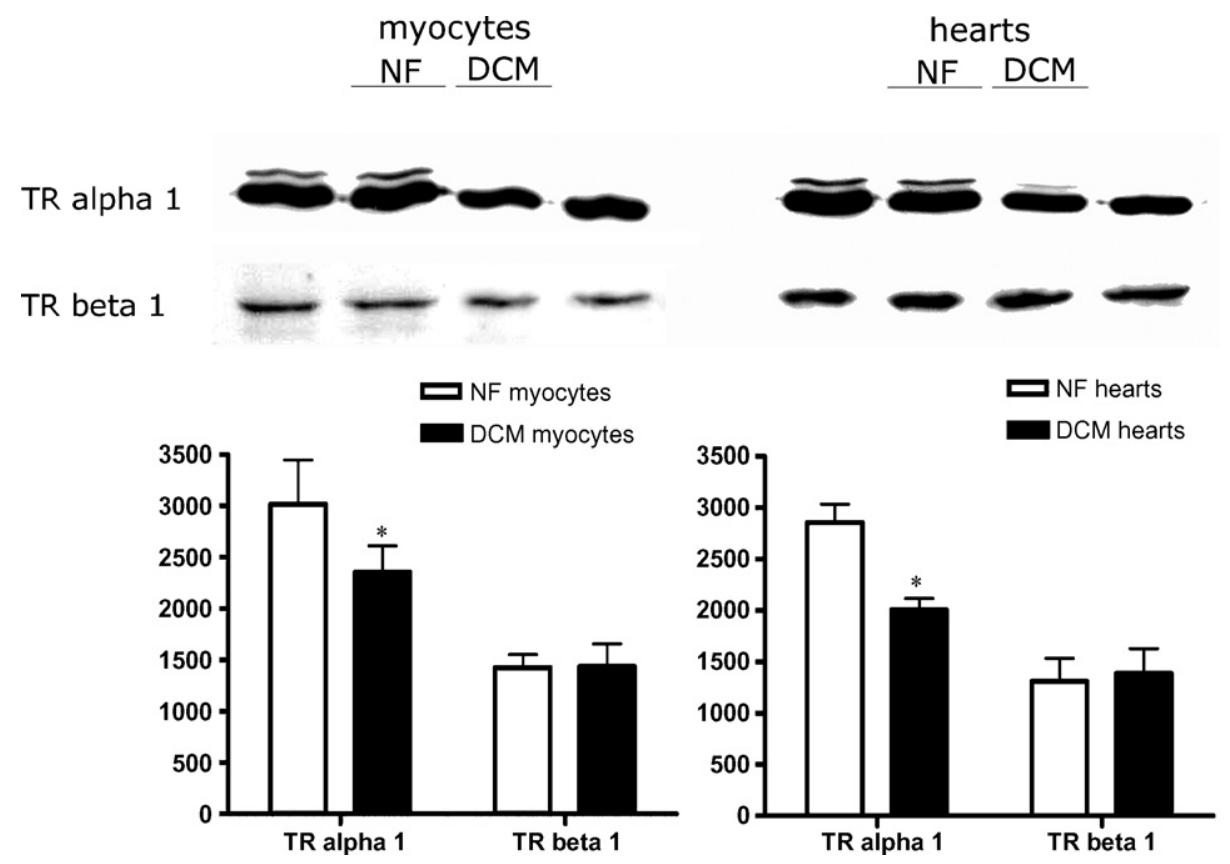

Fig. 2 - Protein expression of thyroid hormone receptors (TR) alpha1, and beta1, in ventricular cardiomyocytes and homogenated hearts from NF and DCM subjects. Upper panels: Representative Western blots. Lower graphs: Bar graphs show the densitometric measurements of Western blots obtained in all subjects investigated $\left({ }^{*} p<0.05\right.$ vs. NF).

treatment of thyroid storm where the use of beta-adrenergic antagonists may acutely impair cardiac function. On the other hand a reduced population of beta-adrenergic receptors as well as their functional impairment [8] characterizes the progression to cardiac failure. Present findings reveal that reduced bARs expression is associated with reduced TRa expression in cardiac tissue. This cardiac tissue hypothyroidism in heart failure may participate in the reduced ARs expression thus resulting in additional possible physiological consequence on cardiac function. Other changes in contractile proteins and regulators of sarcoplasmic calcium

Table 3 - Characterization of beta-adrenergic receptors beta1 (ARB1) and beta2 (ARB2) of isolated myocytes and total cardiac membrane

NF DCM \% of reduction

\begin{tabular}{|c|c|c|c|}
\hline \multicolumn{4}{|l|}{ Myocytes } \\
\hline$B_{\max }$ total (fmol/mg) & $74 \pm 9$ & $38 \pm 3^{*}$ & -48 \\
\hline ARB1:ARB2 & $55: 45$ & $44: 56$ & \\
\hline $\mathrm{Ki}_{\mathrm{met}} \mathrm{ARB1}(\mathrm{nmol} / \mathrm{L})$ & $40 \pm 20$ & $35 \pm 20$ & \\
\hline $\mathrm{Ki}_{\text {ICI }}$ ARB2 (nmol/L) & $170 \pm 60$ & $180 \pm 90$ & \\
\hline$B_{\max }$ ARB1 (fmol/mg) & $37 \pm 3$ & $17 \pm 5^{*}$ & -54 \\
\hline$B_{\max }$ ARB2 (fmol/mg) & $30 \pm 3$ & $21 \pm 4^{*}$ & -30 \\
\hline \multicolumn{4}{|l|}{ Total cardiac tissue } \\
\hline$B_{\max }$ total (fmol/mg) & $100 \pm 10$ & $76 \pm 3^{*}$ & -24 \\
\hline ARB1:ARB2 & $64: 36$ & $51: 49$ & \\
\hline $\mathrm{Ki}_{\mathrm{met}} \mathrm{ARB1}(\mathrm{nmol} / \mathrm{L})$ & $60 \pm 30$ & $50 \pm 15$ & \\
\hline $\mathrm{Ki}_{\text {ICI }}$ ARB2 $(\mathrm{nmol} / \mathrm{L})$ & $65 \pm 20$ & $50 \pm 28$ & \\
\hline$B_{\max }$ ARB1 (fmol/mg) & $62 \pm 6$ & $40 \pm 10^{*}$ & -35 \\
\hline$B_{\max }$ ARB2 (fmol/mg) & $38 \pm 5$ & $40 \pm 10$ & \\
\hline
\end{tabular}

handling were found to be similar in heart failure and hypothyroidism [9-11]. In addition the echocardiographic ejection fraction and mortality was found to be significantly correlated with the serum thyrotropin concentration in dilated cardiomyopathy [23] and a low T3 syndrome, characterized by low circulating levels of the biologically active form of $\mathrm{T} 3$ in the presence of normal thyrotropin (TSH) and of thyroxine was reported to occur in approximately $30 \%$ of patients with advanced heart failure [12]. Serum-free T3 plasma levels in our DCM patients were significantly lower than in controls, but no subject had fT3 values lower than reference limits [12]. Although serum-free T3 and total T3 were found strongly correlated [12], total T3 [24] and not serum-free T3 [25] were found to be related with changes in cardiac function so that total T3 is preferable to fT3 measures in setting of CHF. Unfortunately, in the present study the serum concentration of total thyroxine could not be measured.

The relationship between low serum concentrations of triiodothyronine and impaired cardiovascular hemodynamics, along with the inotropic and vasodilative effects of triiodothyronine, provided a rationale for the clinical use of triiodothyronine to support cardiovascular performance. L-Thyroxine treatment was also proposed in idiopathic dilated cardiomyopathy [26]. Administration of triiodothyronine showed favourable results in uncontrolled clinical studies performed in patients undergoing coronary artery bypass surgery [27], or heart transplantation [28]. However, these results were not confirmed in a controlled clinical trial investigating the effects of the perioperative administration of triiodothyronine in patients undergoing coronary artery bypass surgery [29]. In particular triiodothyronine did not decreases perioperative mortality and the need for traditional 
inotropic agents in patients with preexisting impairment of ventricular function [29].

In a therapeutic context to combat reactivation of fetal gene expression thyroid hormone is also hampered by controversial results of investigations of TR mRNA expression in failing human hearts. Kinugawa et al. [15] reported that the failing human heart possesses higher levels of TRa2, with diminished levels of TR a1, and unchanged TRb1 [15]. Other investigations of TR mRNA expression in the left ventricles of failing human hearts found an increased expression of TRb1 with lowered levels of TRa1 when compared to donor hearts [16] or even an increased expression of all TR [17]. Adding to this complexity, Kinugawa et al. [30] reported that TR expression is linked to the kind of hypertrophic stimulation, namely physiological versus pathological. Physiological stimulation was associated with increased SERCA2a and a-MHC gene expression, and b-MHC repression. Further experiments identified $\mathrm{TRb}$ to mediate the physiological response, while TRa1 and -2 mediate the pathological response [30]. Interestingly, TRb expression was found to be up-regulated when cultured cardiomyocytes were incubated with thyroid hormone, which may explain the clinical observation that short-term thyroid hormone treatment is beneficial in heart failure [31]. Therefore, studies performed on tissue homogenates of human failing hearts yielded conflicting results. However the investigation of homogenated heart does not allow to selectively assess the participation of different cell types. Therefore the use of isolated human ventricular myocytes certainly constitutes an advance because the present findings demonstrates reduced gene expression of adrenoreceptor (AR) b1 and TRa1 not only in human failing myocardium but specially in isolated cardiomyocytes when compared with non-failing myocardium and cardiomyocytes. The total expression of mRNA for TRalpha receptor was reduced when compared to control cells although we did not observe an increased mRNA expression of the TRalpha2 isoform, probably due to the low sensitivity of our methods.

The reduction in thyroid hormone receptors was closely associated with a reduced myocyte expression of both beta1and beta2-adrenergic receptors. Although the reduction of cardiac beta-adrenergic receptors is known to characterize the progression to failure [20], at our knowledge the present is the first study investigating adrenergic receptors in isolated failing human ventricular myocytes. This aspect might be important because the administration of thyroid hormone in patients with heart failure improved cardiac output, left ventricular ejection fraction, and decreased isovolumetric relaxation time with a parallel induction of a beta-adrenergic receptor upregulation on peripheral lymphocyte surfaces [32]. Therefore it cannot be excluded that the reduced expression of the active form of thyroid receptor hormone might play a role in beta1adrenergic receptor reduction in human heart failure. On the other hand the $\mathrm{TH}$ receptor alteration may also represent a defensive mechanism for the myocyte to reduce oxygen consumption.

In conclusion, in addition to the impaired population of adrenergic receptors, a reduced expression of thyroid hormone receptors characterizes cardiac myocytes changes in advanced heart failure.

\section{Acknowledgement}

This work was supported by the Ministero dell'Università e della Ricerca Scientifica e Tecnologica, Rome, Italy (grant no. 2003063257-006, to P.A. Modesti).

\section{R E F E R E N C E S}

[1] Klein I, Ojamaa K. Thyroid hormone and the cardiovascular system. N Engl J Med 2001;344:501-9.

[2] Biondi B, Fazio S, Carella C, Sabatini D, Amato G, Cittadini $A$, et al. Control of adrenergic overactivity by beta-blockade improves the quality of life in patients receiving long term suppressive therapy with levothyroxine. J Clin Endocrinol Metab 1994;78:1028-33.

[3] Rohrer D, Dillmann WH. Thyroid hormone markedly increased the mRNA coding for sarcoplasmic reticulum $\mathrm{Ca}^{++}$ATPase in the rat heart. J Biol Chem 1988;263: 6941-4.

[4] Bahouth SW, Cui X, Beauchamp MJ, Park EA. Thyroid hormone induces beta1-adrenergic receptor gene transcription through a direct repeat separated by five nucleotides. J Mol Cell Cardiol 1997;29:3223-37.

[5] Izumo S, Nadal-Ginard B, Mahdavi V. All members of the MHC multigene family respond to thyroid hormone in a highly tissue-specific manner. Science 1986;231:597600.

[6] Ojamaa K, Klemperer JD, MacGilvray SS, Klein, Samarel A. Thyroid hormone and hemodynamic regulation of betamyosin heavy chain promoter in the heart. Endocrinology 1996;137:802-8.

[7] Nishiyama A, Kambe F, Kamiya K, Seo H, Toyama J. Effects of thyroid status on expression of voltage-gated potassium channels in rat left ventricle. Cardiovasc Res 1998;40:34351.

[8] Bristow MR, Minobe WA, Raynolds MV, Port JD, Rasmussen $\mathrm{R}$, Ray PE, et al. Reduced beta 1 receptor messenger RNA abundance in the failing human heart. J Clin Invest 1993;92:2737-45.

[9] Lowes BD, Minobe W, Abraham WT, Rizeq MN, Bohlmeyer TJ, Quaife RA, et al. Changes in gene expression in the intact human heart. Downregulation of alpha-myosin heavy chain in hypertrophied, failing ventricular myocardium. J Clin Invest 1997;100:2315-24.

[10] Klein I. Thyroid and the heart. Thyroid 2002;12:439.

[11] Danzi S, Klein I. Thyroid hormone-regulated cardiac gene expression and cardiovascular disease. Thyroid 2002;12:467-72.

[12] Iervasi G, Pingitore A, Landi P, Raciti M, Ripoli A, Scarlattini $M$, et al. Low-T3 syndrome: a strong prognostic predictor of death in patients with heart disease. Circulation 2003;107:708-13.

[13] Nakao K, Minobe W, Roden R, Bristow MR, Leinwand LA. Myosin heavy chain gene expression in human heart failure. J Clin Invest 1997;100:2362-70.

[14] Miyata S, Minobe W, Bristow MR, Leinwand LA. Myosin heavy chain isoform expression in the failing and nonfailing human heart. Circ Res 2000;86:386-90.

[15] Kinugawa K, Minobe WA, Wood WM, Ridgway EC, Baxter JD, Ribeiro RC, et al. Signaling pathways responsible for fetal gene induction in the failing human heart: evidence for altered thyroid hormone receptor gene expression. Circulation 2001;103:1089-94.

[16] Sylvén C, Jansson E, Sotonyi P, Waagstein F, Barkhem T, Bronnegard M. Cardiac nuclear hormone receptor mRNA in heart failure in man. Life Sci 1996;59:1917-22. 
[17] d'Amati G, di Gioia CR, Mentuccia D, Pistilli D, ProiettiPannunzi L, Miraldi F, et al. Increased expression of thyroid hormone receptor isoforms in end-stage human congestive heart failure. J Clin Endocrinol Metab 2001;86:2080-4.

[18] Modesti PA, Vanni S, Paniccia R, Bandinelli B, Bertolozzi I, Polidori G, et al. Characterization of endothelin-1 receptor subtypes in isolated human cardiomyocytes. J Cardiovasc Pharmacol 1999;34:333-9.

[19] Modesti A, Bertolozzi I, Gamberi T, Marchetta M, Lumachi C, Coppo M, et al. Hyperglycemia activates JAK2 signaling pathway in human failing myocytes via angiotensin IImediated oxidative stress. Diabetes 2005;54:394-401.

[20] Engelhardt S, Bohm M, Erdmann E, Lohse MJ. Analysis of beta-adrenergic receptor mRNA levels in human ventricular biopsy specimens by quantitative polymerase chain reactions: progressive reduction of beta 1-adrenergic receptor mRNA in heart failure. J Am Coll Cardiol 1996;27:146-54.

[21] Neri Serneri GG, Cecioni I, Vanni S, Paniccia R, Bandinelli B, Vetere A, et al. Selective upregulation of cardiac endothelin system in patients with ischemic but not idiopathic dilated cardiomyopathy: endothelin-1 system in the human failing heart. Circ Res 2000;86:377-85.

[22] Walker JD, Crawford Jr FA, Mukherjee R, Spinale FG. The direct effects of 3,5,3'-triiodo-L-thyronine (T3) on myocyte contractile processes. Insights into mechanisms of action. J Thorac Cardiovasc Surg 1995;110:1369-79.

[23] Kozdag G, Ural D, Vural A, Agacdiken A, Kahraman G, Sahin $\mathrm{T}$, et al. Relation between free triiodothyronine/free thyroxine ratio, echocardiographic parameters and mortality in dilated cardiomyopathy. Eur J Heart Fail 2005;7:113-8.

[24] Pingitore A, Iervasi G, Barison A, Prontera C, Pratali L, Emdin M, et al. Early activation of an altered thyroid hormone profile in asymptomatic or mildly symptomatic idiopathic left ventricular dysfunction. J Card Fail 2006;12:520-6.

[25] Calvo-Romero JM, Rodriguez EM. Serum-free thyroxine and thyrotropin concentrations in euthyroid patients with decompensated congestive heart failure. Int J Cardiol 2005;102:367-8.

[26] Moruzzi P, Doria E, Agostoni PG, Capacchione V, Sganzerla P. Usefulness of L-thyroxine to improve cardiac and exercise performance in idiopathic dilated cardiomyopathy. Am J Cardiol 1994;73:374-8.

[27] Novitzky D, Cooper DKC, Swanepoel A. Inotropic effect of triiodothyronine (T3) in low cardiac output following cardioplegic arrest and cardiopulmonary bypass: an initial experience in patients undergoing open heart surgery. Eur J Cardiothorac Surg 1989;3:140-5.

[28] Jeevanandam V, Todd B, Regillo T, Hellman S, Eldridge C, McClurken J. Reversal of donor myocardial dysfunction by triiodothyronine replacement therapy. J Heart Lung Transplant 1994;13:681-7.

[29] Klemperer JD, Klein I, Gomez M, Helm RE, Ojamaa K, Thomas SJ, et al. Thyroid hormone treatment after coronary-artery bypass surgery. N Engl J Med 1995;333:1522-7.

[30] Kinugawa K, Yonekura K, Ribeiro RC, Eto Y, Aoyagi T, Baxter JD, et al. Regulation of thyroid hormone receptor isoforms in physiological and pathological cardiac hypertrophy. Circ Res 2001;89:591-8.

[31] Hamilton MA, Stevenson LW, Fonarow GC, Steimle A, Goldhaber JI, Child JS, et al. Safety and hemodynamic effects of intravenous triiodothyronine in advanced congestive heart failure. Am J Cardiol 1998;81:443-7.

[32] Lu X, Huang J, Zhang X, Li X, Wang C, Zhang P, et al. Effects of thyroxine on cardiac function and lymphocyte betaadrenoreceptors in patients with chronic congestive heart failure. Chin Med J (Engl) 2003;116:1697-700. 